\title{
Adsorptive Removal of Selected Anionic and Cationic Dyes by Using Graphitic Carbon Material Prepared from Edible Sugar: A Study of Kinetics and Isotherms
}

\author{
Lakshmi Prasanna Lingamdinne, ${ }^{1}$ Jong-Soo Choi, ${ }^{1}$ Jae-Kyu Yang, ${ }^{2}$ \\ Yoon-Young Chang, ${ }^{1}$ Janardhan Reddy Koduru ${ }^{1, *}$ and Jiwan Singh ${ }^{3, *}$ \\ ${ }^{1}$ Department of Environmental Engineering, Kwangwoon University, Seoul 01897, Republic of Korea. \\ ${ }^{2}$ Ingenium College of Liberal Arts, Kwangwoon University, Seoul 01897, Republic of Korea. \\ ${ }^{3}$ Department of Environmental Science, Babasaheb Bhimrao Ambedkar University, Lucknow-226025, India. \\ *Corresponding author: E-mail: reddyjchem@gmail.com; jiwansingh95@gmail.com \\ Phone: +82-2-940-5496; Fax: +82-2-9185774
}

Received: 07-02-2018

\begin{abstract}
Graphitic carbon-like material (GCM) derived from edible sugar under a nitrogen environment was applied as an adsorbent for the removal of anionic and cationic dyes (methyl orange, $\mathrm{MO}$ ) and methylene blue (MB) from wastewater. The physico-chemical characterization of GCM was analyzed by scanning electron microscopy (SEM), X-ray diffraction (XRD), Fourier transform infrared (FT-IR) spectroscopy, and X-ray photoelectron spectroscopy (XPS). The plate-like morphology with an average size of 50-100 nm was measured from the SEM images. The measured BET 'surface area and pore volume were $574 \mathrm{~m}^{2} / \mathrm{g}$ and $0.248 \mathrm{~cm}^{3} / \mathrm{g}$, respectively with pore diameter $(d), 1.847(<2 \mathrm{~nm})$ indicates that the GCM classified as a microporous. The effects of dosage, $\mathrm{pH}$, contact time and concentration on the adsorption of MB and MO onto GCM were studied to unveil the adsorption process. The experimental isotherm data concurred with the Langmuir isotherm model $\left(\mathrm{R}^{2}=0.990\right)$ for $\mathrm{MB}$, while the MO isotherm data concurred with Freundlich model $\left(\mathrm{R}^{2}=0.995\right)$. The maximum adsorption capacity achieved from the Langmuir isotherm equation at $25^{\circ} \mathrm{C}$ was 38.75 and $43.48 \mathrm{mg} / \mathrm{g}$ for $\mathrm{MB}$ and MO, respectively, which indicates that GCM is a suitable adsorbent for the adsorption of both anionic and cationic dyes. The kinetic study demonstrated that the adsorption of both dyes onto GCM was the pseudo-second-order diffusion kinetics. The thermodynamic parameters reveal the adsorption of both dyes was endothermic spontaneous through chemical interactions. The GCM was found to be a potential adsorbent for the removal of MB and MO from an aqueous solution.
\end{abstract}

Keywords: Graphitic carbon material; Anionic dye; Cationic dye; Adsorption efficiency; Kinetics isotherms; Thermodynamics

\section{Introduction}

The releasing of dye-containing wastewaters in to the environment is a significant cause of poor water quality, and leads to eutrophication and distressing aquatic life. Dye-containing wastewater can increase the toxicity, biochemical oxygen demand, and chemical oxygen demand of the affected water. ${ }^{1}$ Therefore, developing a cost-effective process for the removal of dyes from the effluents of industries has been one of the most challenging tasks around the world. Many treatment methods including physical, chemical, and biological methods have been re- ported to remove dyes from wastewater. ${ }^{2}$ However, these methods have a number of disadvantages, such as the production of large amounts of toxic and carcinogenic byproducts, and are not cost-effective. ${ }^{3}$ Adsorption is an economic, effective, and easily operated process in dye removal. ${ }^{4}$ Hence, continued attempts have been made by investigators to discover a new adsorbent material which can give results that are more efficient. Methylene blue $(\mathrm{MB})$ is a cationic dye and is most commonly used for dying materials such as wood, silk, and cotton. ${ }^{5}$ Methyl orange (MO) is an acidic/anionic dye, and has been widely used in the textile, printing, paper, food, and pharmaceuti- 
cal industries. ${ }^{6}$ Because of their toxic nature, the removal of $\mathrm{MO}$ and MB from wastewater is essential. ${ }^{5,7}$

Graphene is an attractive new material composed of carbon ingredients with a honeycomb-like structure. It has motivated massive interest over the last few years because of its excellent properties such as stability, ${ }^{8}$ high thermal conductivity, ${ }^{9}$ and fast mobility of charge carriers. ${ }^{10}$ Various studies have shown that graphene/graphene oxide is a perfect material for the removal of dyes due to its good mechanical strength, large surface area, 2D structure, abundant surface functional groups, and its electrostatic interaction with cationic dyes. ${ }^{11-13}$ However, the preparation of graphene from graphite is expensive and using toxic chemicals. A biologically derived graphene is possibly the most reasonable and chemically most adaptable graphene. Graphene or carbon-like materials derived from plant sources are typically eco-friendlier than those from fossil sources such as petroleum. There are many reports prepared carbon materials from biomaterials or plant continents and were utilized for adsorption. ${ }^{14}$ Edible sugar is one of the simplest natural sources of carbon, and converts completely into elemental carbon upon dehydration. ${ }^{15}$

In this work, we report the results of the adsorption of an anionic dye (MO) and a cationic dye (MB) on a sugar-based graphitic carbon-like material (GCM). We developed GCM from a low-cost crystal sugar in the presence of nitrogen gas. Crystal sugar is a type of edible sugar, an inexpensive and sustainable raw material that can be easily produced from agricultural products such as sugar cane and beet. Synthesized low-cost GCM was examined as an adsorbent for the removal of $\mathrm{MB}$ and $\mathrm{MO}$ from aqueous solutions. Studies were conducted with a parameter (equilibrium time, $\mathrm{pH}$, temperature, and initial dye concentra- tion) that affect the adsorption process. Kinetic models and isotherm models were also studied. This study clearly confirmed that GCM signified a high adsorption performance for the removal of the both dyes ( $\mathrm{MB}$ and $\mathrm{MO}$ ) from aqueous solutions. Moreover, the adsorption capacity of GCM for MB and MO was comparable or near with previous reported similar activated carbons or graphene type materials. $5,13,16,17$ Hence, as prepared GCM has potential adsorption capacity for the removal organic dye pollutants and thereby significant reducing human health and environmental risks.

\section{Experimental}

\section{1. Materials}

Methylene Blue (molecular formula $\mathrm{C}_{16} \mathrm{H}_{18} \mathrm{ClN}_{3} \mathrm{~S}$. $\left.3 \mathrm{H}_{2} \mathrm{O}\right)$ and methyl orange $\left(\mathrm{C}_{14} \mathrm{H}_{14} \mathrm{~N}_{3} \mathrm{NaO}_{3} \mathrm{~S}\right)$ were purchased from Samchun pure chemical Co., Ltd. Korea. Edible sugar was purchased from the local market. Figure 1 represents the molecular structure of $\mathrm{MB}$ and $\mathrm{MO}$.

\section{2. Preparation of the GCM}

Scheme 1 represents the synthesis of graphitic carbon-like material (GCM) from the edible sugar. At first, the sugar was dissolved in water thoroughly, then the mixture was heated at $\sim 120{ }^{\circ} \mathrm{C}$ with continuous stirring for getting caramel. The sugar solution (caramel) was then transferred to a silica crucible and heated in a furnace at $\mathrm{N}_{2}$ atmosphere.

The furnace temperature was programmed as follows: (a) from room temperature to $100^{\circ} \mathrm{C}$ in $30 \mathrm{~min}$, (b) a)<smiles>CN(C)c1ccc2nc3ccc(=[N+](C)C)cc-3sc2c1</smiles>

b)<smiles>CN(C)c1ccc(/N=N/c2ccc(S(=O)(=O)[O-])cc2)cc1</smiles>

Figure 1. The molecular structure of $\mathrm{MB}(\mathrm{a})$ and $\mathrm{MO}(\mathrm{b})$.

$$
\mathrm{C}_{12} \mathrm{H}_{22} \mathrm{O}_{11} \text { (Sugar) } \stackrel{\triangle}{\rightarrow} 12 \mathrm{C}+11 \mathrm{H}_{2} \mathrm{O}
$$

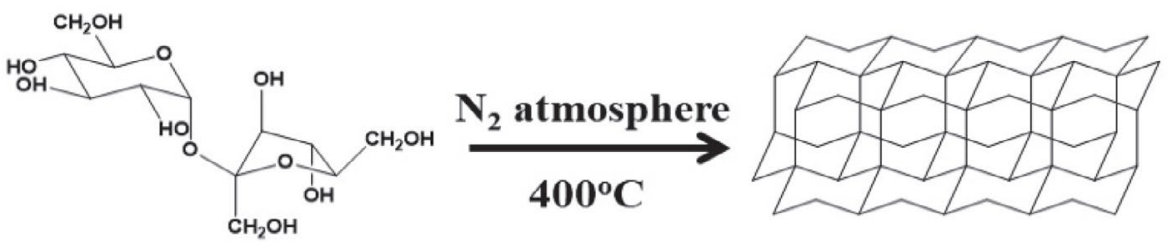

\begin{tabular}{|l|l|}
\hline Sugar (Sucrose) & Graphitic Carbon Like Material \\
\hline
\end{tabular}

Scheme 1. The schematic representation of the green synthesis of graphitic carbon material (GCM) from edible sugar. 
$100-200{ }^{\circ} \mathrm{C}$ in $30 \mathrm{~min}\left(\mathrm{c}\right.$ ), held at $200^{\circ} \mathrm{C}$ for $1 \mathrm{~h}$ (sugar melting point of sucrose is around $186^{\circ} \mathrm{C}$ ), (d) ramped to $400{ }^{\circ} \mathrm{C}$ in $1 \mathrm{~h}$, and (e) held for $3 \mathrm{~h}$ at $400{ }^{\circ} \mathrm{C}$ (to ensure complete graphitization of sugar). The furnace was then switched off and the material was cooled down to room temperature. The temperature of $400 \pm 5^{\circ} \mathrm{C}$ was chosen as the final temperature after several experiments showed this to provide optimized results. No special care was taken in controlling the cooling rate. The black material obtained was named as the graphitic carbon-like material (GCM).

\section{3. Adsorption Experiments}

A batch study was carried out for the evaluation of adsorption equilibrium and kinetic studies of $M B$ and MO. The effects of different operating parameters (solution $\mathrm{pH}$, adsorbent dosage, initial $\mathrm{MB}$ concentration, contact time, and temperature) were studied about $\mathrm{MB}$ and MO removal using the GCM. Enough adsorbent dose was added to separate solutions of $50 \mathrm{~mL}$ of $\mathrm{MB}$ and $50 \mathrm{~mL}$ of $\mathrm{MO}$ at the desired concentrations. These solutions were placed into $100 \mathrm{~mL}$ glass flasks and the samples were then shaken at $25 \pm 0.5^{\circ} \mathrm{C}$. The effect of the $\mathrm{pH}$ on the adsorption of $\mathrm{MB}$ and $\mathrm{MO}$ was studied while varying the $\mathrm{pH}$ values in the range of 2 to 10 . Various adsorbent dosages $(0.5$, $1.0,2.0$, and $4.0 \mathrm{~g} / \mathrm{L})$ were mixed in a dye solution $(50 \mathrm{~mL})$ in a concentration range of 5 to $50 \mathrm{mg} / \mathrm{L}$. These solutions were then continuously stirred at $60 \mathrm{rpm}$ in a water bath shaker. Samples were collected at different times. After reach adsorption equilibrium, the residue dye concentration in the solutions was measured using a UV-Vis spectrophotometer (UV 1601, Shimadzu) with maximum wavelength $\left(\lambda_{\max }\right)$ of $665 \mathrm{~nm}$ and $465 \mathrm{~nm}$ for $\mathrm{MB}$ and $\mathrm{MO}$, respectively. Experiments were performed in triplicate to check the reproducibility of the data.

The adsorption amount and adsorption efficiency of $\mathrm{MB}$ and $\mathrm{MO}$ were calculated according to Eqs. 1 and 2 as follows:

$$
\begin{aligned}
& q e=\left(C_{0}-C_{\mathrm{e}}\right) \mathrm{V} / \mathrm{W} \\
& q e=\left(C_{0}-C_{\mathrm{t}}\right) \mathrm{V} / \mathrm{W}
\end{aligned}
$$

$$
\text { Removal efficiency }(\%)=\left(\left(C_{0}-C_{\mathrm{e}}\right) / C_{0}\right) \times 100
$$

where $\mathrm{C}_{0}(\mathrm{mg} / \mathrm{L})$ is the initial MB or MO concentration, $\mathrm{Ce}(\mathrm{mg} / \mathrm{L})$ is the $\mathrm{MB}$ or $\mathrm{MO}$ equilibrium concentration at equilibrium time $\mathrm{t}(\mathrm{min}), \mathrm{V}(\mathrm{L})$ is volume of solution, $\mathrm{W}$ $(\mathrm{g})$ is the weight of adsorbent, and $\mathrm{q}_{\mathrm{e}}(\mathrm{mg} / \mathrm{g})$ is the amount of $\mathrm{MB}$ or $\mathrm{MO}$ adsorbed by GCM.

\section{4. Instrumental Analysis}

Scanning electron microscopy (SEM) and energy-dispersive X-ray spectroscopy (EDS) (S-4300 \& EDX-
350, Hitachi, Japan) were used to measure the surface morphology GCM. To identify the functional groups in the GCM, a Fourier transform infrared (FT-IR) spectrometer (Perkin-Elmer, USA) was used. X-ray diffraction (XRD) analysis of the GCM nanoparticles was conducted using a D/Max-2500 diffractometer (Rigaku, Japan). Elemental composition analysis of GCM was performed by using ESCALAB-210 (Spain) X-ray photoelectron spectroscopy (XPS). Quantachrome Instruments (Boynton Beach, FL, USA) was used to Brunauer-Emmett-Teller (BET) surface analysis of GCM.

\section{Results and Discussion}

\section{1. Characterizations of GCM}

Figure $2 \mathrm{a}$ and $2 \mathrm{~b}$ present the SEM images of the GCM at low and high resolution respectively, showing the rough surface morphology of GCM, indicating the considerable adsorption potential of $\mathrm{MB}$ and $\mathrm{MO}$. The structure and morphology of the GCM were investigated from the SEM images. A plate-like morphology with an average size of 50-100 nm was detected from the magnification images. The XRD pattern (Fig. 2c) of the GCM shows a broad peak at $2 \theta=23.4^{\circ}$, corresponding to the phase of graphitic hexagonal carbon (JCPDF No: 75-1621 of graphene XRD pattern); however, the small peaks located at $43.5^{\circ}$ could be attributed to the characteristic peaks of the oxidized form of GCM. ${ }^{18}$ The crystalline nature of GCM is also concluded from that the XRD pattern. The surface physical characteristics of GCM was measured by using BrunauerEmmett-Teller (BET) surface analysis with nitrogen $\left(\mathrm{N}_{2}\right)$ adsorption-desorption isotherms. It was found that the surface area and pore volume was $574 \mathrm{~m}^{2} / \mathrm{g}$ and 0.248 $\mathrm{cm}^{3} / \mathrm{g}$, respectively. And the measured pore diameter $(d)$, $1.847(<2 \mathrm{~nm})$ indicates that the GCM classified as a microporous crystalline material.

To better understand the functional groups of the GCM, we applied Fourier transform infrared (FT-IR) spectroscopy, as shown in Figure 3a. The FT-IR spectra of the GCM shows the availability of numerous functional groups before and after adsorption. The peaks occur at $1200 \mathrm{~cm}^{-1}$ on GCM, which might have designated -C-O-C- stretching vibrations. However, after adsorption, this peak was broadened and shifted at $1170.3 \mathrm{~cm}^{-1}$ and $1178.4 \mathrm{~cm}^{-1}$, confirming the adsorption of $\mathrm{MB}$ and $\mathrm{MO}$, respectively, onto the GCM. While a peak at 1598.7 $\mathrm{cm}^{-1}$ was observed on GCM, after adsorption of $\mathrm{MB}$ and $\mathrm{MO}$, this peak shifted to $1590.4 \mathrm{~cm}^{-1}$ and the peak intensity increased, representing the $-\mathrm{C}=\mathrm{C}$ - stretching vibrations. ${ }^{19}$ A peak at $1717 \mathrm{~cm}^{-1}$ on GCM was also observed before and after adsorption, and the peak intensity increased after adsorption of both dyes, representing the $\mathrm{C}=\mathrm{O}$ stretching vibrations. ${ }^{19}$

The GCM sample is analyzed by XPS in the range of binding energies, $0.0-1400 \mathrm{eV}$. The XPS survey (Fig. 3b) 

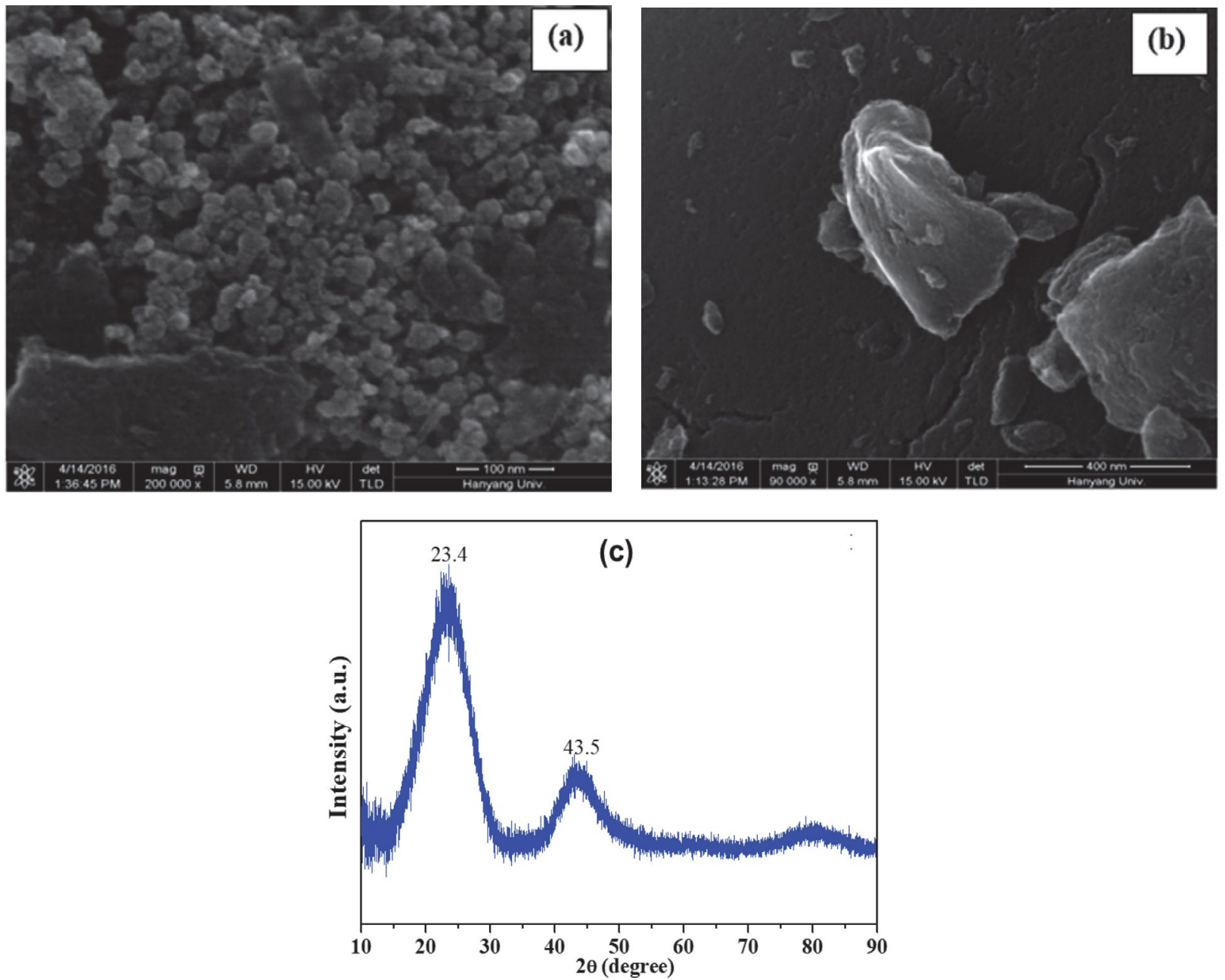

Figure 2. SEM images of GCM (a \& b) and XRD spectra (c) of GCM.

a)

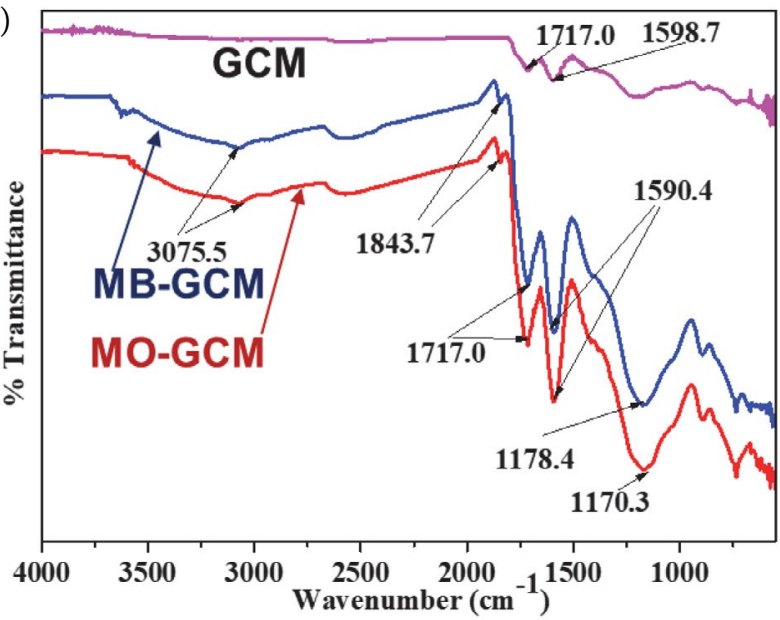

b)

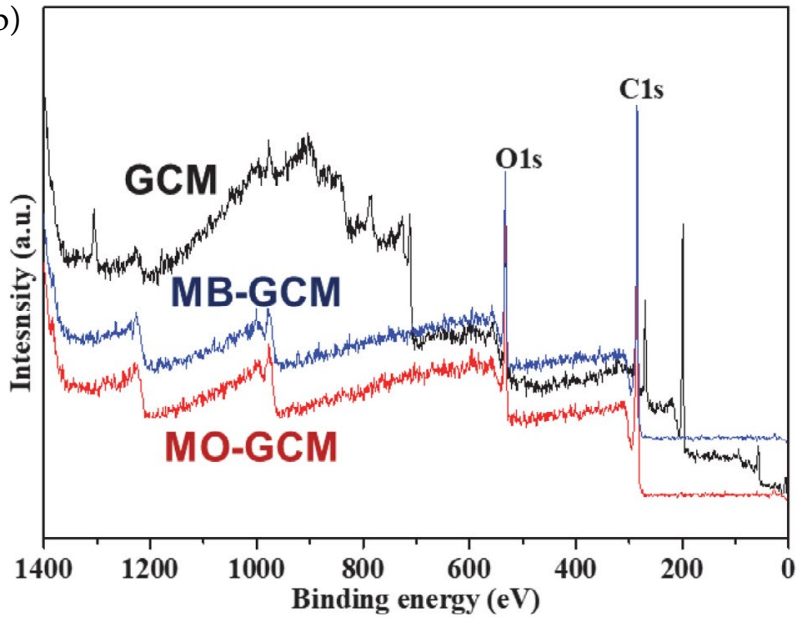

Figure 3. FT-IR spectra (a) and XPS spectra (b) of GCM and dyes loaded GCM.

of the GCM shows the presence of $\mathrm{O}$ and $\mathrm{C}$ elements. The presence of a high percentage of non-oxygenated $\mathrm{C} 1 \mathrm{~s}$ (peak centered at $285.8 \mathrm{eV}$ ) indicates the presence of a carbon backbone. The O1s spectrum shows a peak at
$532.2 \mathrm{eV}$, which might represent $-\mathrm{C}-\mathrm{O}$ from carbonyl, epoxy or carboxylic groups. ${ }^{18}$ The intensities of the peaks of $\mathrm{C} 1 \mathrm{~s}$ and $\mathrm{O} 1 \mathrm{~s}$ were increased after the adsorption of $\mathrm{MB}$ and MO. 


\section{2. Effect of Operational Parameters on Adsorption Process of MB and MO onto GCM}

The effect of adsorbent mass on the removal of pollutants was studied to select the suitable amount of adsorbent for industrial applications. The effect of adsorbent dose on the $\mathrm{MB}$ and $\mathrm{MO}$ removal was studied by changing the dosages of GCM from 0.5 to $4.0 \mathrm{~g} / \mathrm{L}$ (experimental conditions: $\mathrm{MB}$ or $\mathrm{MO}$ initial concentration of $10 \mathrm{mg} / \mathrm{L}$, $\mathrm{pH} 8$, temperature of $25^{\circ} \mathrm{C}$, shaking speed of $60 \mathrm{rpm}$, and shaking time of $420 \mathrm{~min}$ ) (Figs. $4 \mathrm{a}$ and $4 \mathrm{~b}$ ).

The removal efficiencies of MB and MO increased to around $99.9 \%$ and $92.6 \%$, respectively, with the increase of adsorbent dosages; this occurred because more
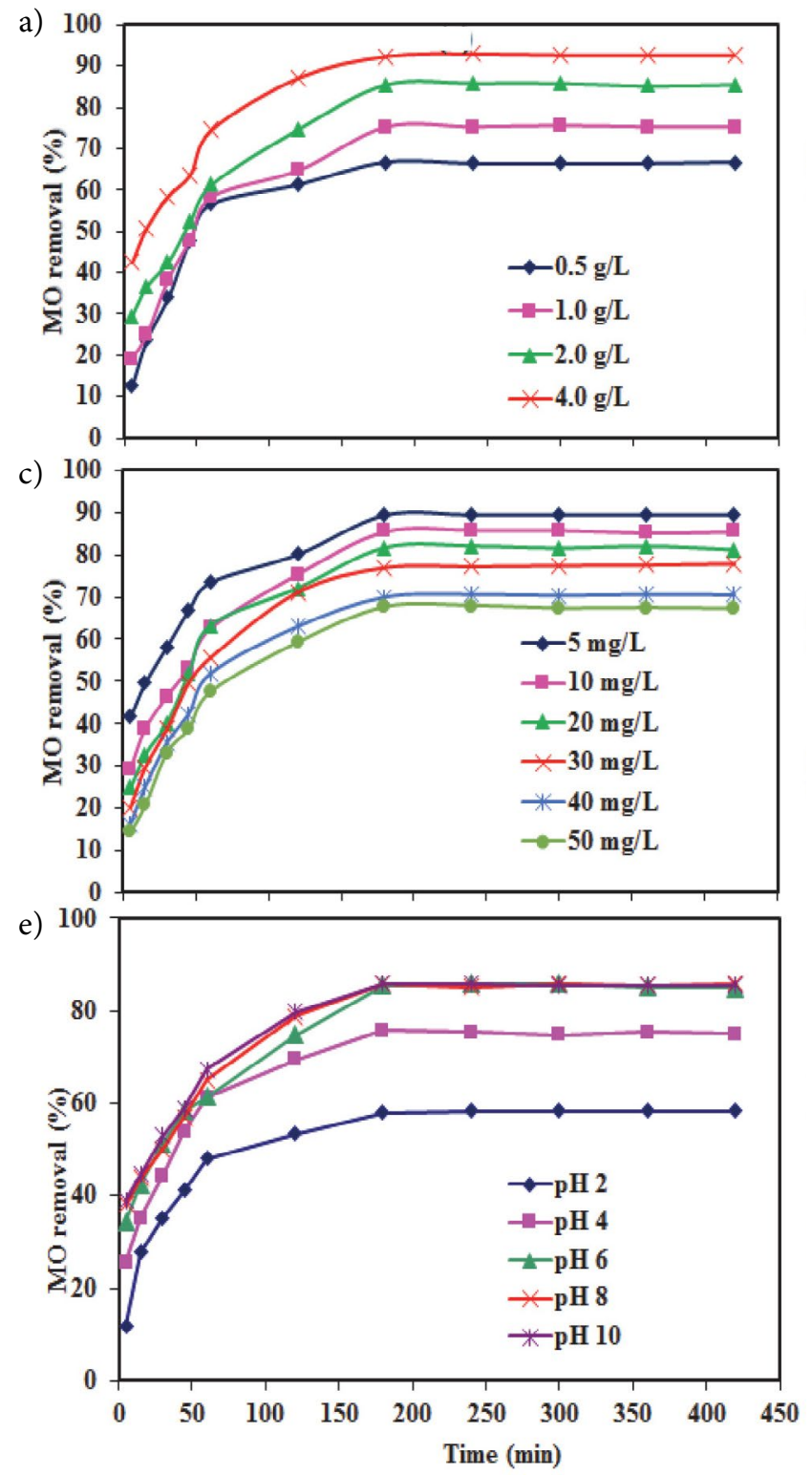

adsorption sites were available at higher adsorbent dosages. ${ }^{20}$ However, the adsorption capacity decreased from 19.5 to $2.6 \mathrm{mg} / \mathrm{g}$ for $\mathrm{MB}$ and from 19.7 to $2.7 \mathrm{mg} / \mathrm{g}$ from MO by increasing the adsorbent dose from 0.5 to $4.0 \mathrm{~g} / \mathrm{L}$. This decrease of adsorption capacity may have occurred in two ways, the first reason is due to the decrease of a number of available adsorption site per unit area by the increase of adsorbent molecules interactions or aggregation of adsorbent molecules as an increase of adsorbent dosage. ${ }^{21}$ The second reason is may be due to the collision between the particles of adsorbent sites and the dye molecules. ${ }^{22}$ Considering the removal efficiency and practicality, the optimal adsorbent dosage was maintained at $2.0 \mathrm{~g} / \mathrm{L}$ for the both $\mathrm{MB}$ and $\mathrm{MO}$ in all subsequent experiments.

b)

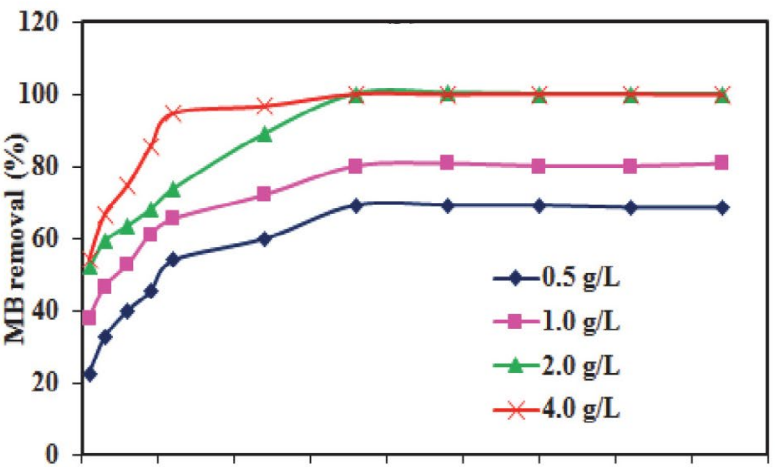

d)

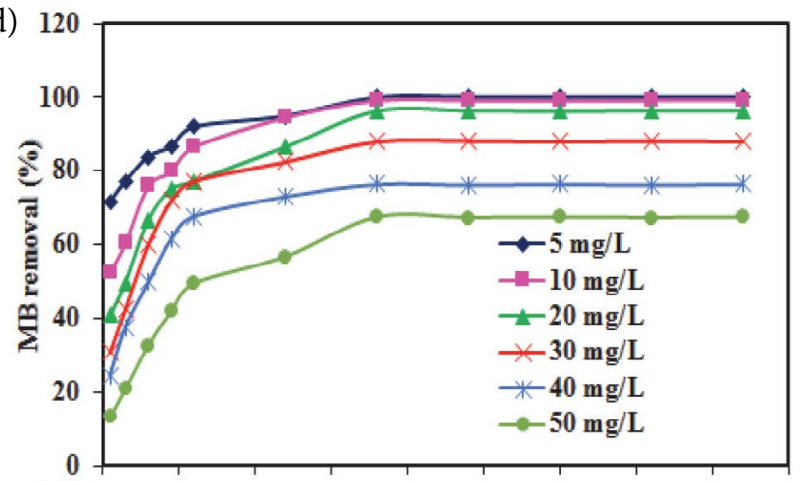

f)

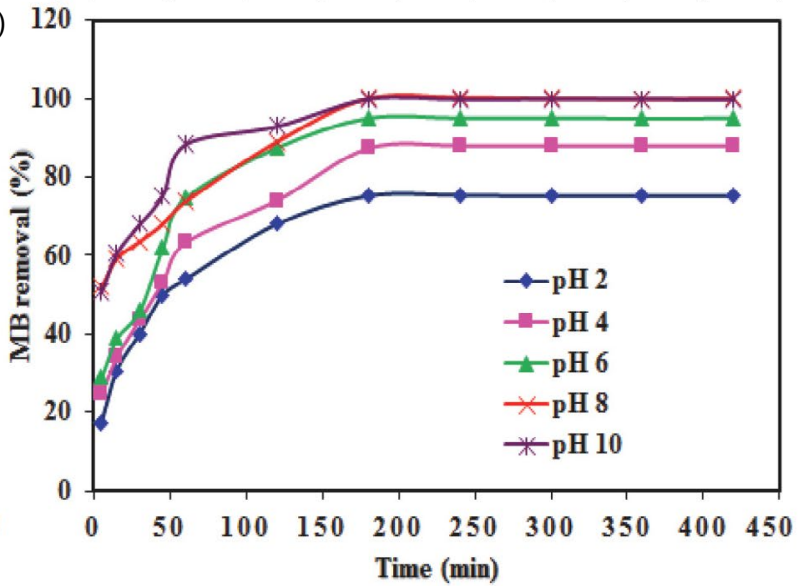

Figure 4. Effects of the different parameters on adsorption of MB and MO: dosages of GCM (a), initial concentrations of dyes (b), and different pH values of aqueous solutions (c). 
The effect of the initial dye concentrations $(5,10,20$, 30,40 , and $50 \mathrm{mg} / \mathrm{L}$ ) on the percentage removal and the uptake $\left(\mathrm{q}_{\mathrm{e}}\right)$ of $\mathrm{MB}$ and $\mathrm{MO}$ was studied (experimental conditions: GCM dose of $2.0 \mathrm{~g} / \mathrm{L}, \mathrm{pH} 8$ for $\mathrm{MB}, \mathrm{pH} 6$ for $\mathrm{MO}$, temperature of $25^{\circ} \mathrm{C}$, shaking speed of $60 \mathrm{rpm}$, and shaking time of $420 \mathrm{~min}$ ) (Figs. $4 \mathrm{c}$ and $4 \mathrm{~d}$ ). The adsorption capacities of $\mathrm{MO}$ and $\mathrm{MB}$ on GCM were increased from 2.6 to $24.3 \mathrm{mg} / \mathrm{g}$ and from 2.5 to $24.0 \mathrm{mg} / \mathrm{g}$, respectively with an increasing concentration of both dyes from 5.0 to $50 \mathrm{mg} / \mathrm{L}$. However, the percentage removal of both dyes was decreased from $89.4 \%$ to $67.5 \%$ and from $99.9 \%$ to $67.3 \%$ for $\mathrm{MO}$ and $\mathrm{MB}$, respectively, with increasing concentration.

Decreased the adsorption removal percentages of $\mathrm{MO}$ and MB on to GCM with increasing dyes initial concentrations, it might be due to the driving force created by the dye molecules, which could resist the mass transfer of the dyes. ${ }^{23}$ The time profile shows that equilibrium of dye uptake was reached after a contact time of $180 \mathrm{~min}$ for both dyes. It was observed that the adsorption capacity of $\mathrm{MO}$ and MB onto the GCM increased with the initial concentration of both dyes during the initial stage, and this increasing tendency continued until equilibrium was reached after $180 \mathrm{~min}$. This can be attributed to the fact that most vacant surface sites of GCM are occupied for the adsorption of dyes during the initial stage, and adsorption of pollutants is difficult in the remaining unoccupied surface sites due to the repulsive forces between the adsorbed dye molecules on the GCM and the bulk phase. ${ }^{24}$

The effect of different solution $\mathrm{pH}$ values $(\mathrm{pH} 2.0$, $4.0,6.0,8.0$, and 10) was studied on the percentage removal and the uptake $\left(\mathrm{q}_{\mathrm{e}}\right)$ of MO and MB (experimental conditions: initial MO or MB concentration of $10 \mathrm{mg} / \mathrm{L}, \mathrm{GCM}$ dose of $2.0 \mathrm{~g} / \mathrm{L}$, temperature of $25^{\circ} \mathrm{C}$, shaking speed of 60 rpm, and shaking time of $7 \mathrm{hr}$ ). The solution $\mathrm{pH}$ values were adjusted by adding $0.1 \mathrm{~N} \mathrm{HCl}$ and $0.1 \mathrm{~N} \mathrm{NaOH}$. As shown in Figure $4 \mathrm{e}$ and $4 \mathrm{f}$, the percentage removal of $\mathrm{MO}$ increased up to the $\mathrm{pH} 6$ solution; however, the percentage removal of $\mathrm{MB}$ was increased up to the $\mathrm{pH} 8$ solution and the further increase in the values of $\mathrm{pH}$ removal percentage was found to be almost constant for both dyes. A very low removal of $\mathrm{MB}$ was observed at an acidic $\mathrm{pH}(\mathrm{pH} 2.0)$, this can be attributed to the repulsive force between the cationic dye (MB) and the surface of GCM. An addition of $\mathrm{H}^{+}$ions might compete with the cation of the MB molecule for vacant adsorption sites of GCM.

The removal percentage of MB on the GCM was increased from $75.0 \%$ to $99.9 \%$ with increasing $\mathrm{pH}$ values from 2.0 to 8.0 . This is due to the increased number of negatively charged sites with maintaining basic $\mathrm{pH}$, which could be favoring the adsorption of MB onto GCM due to the electrostatic force of attraction. ${ }^{24} \mathrm{At} \mathrm{pH}$ above 8 for $\mathrm{MB}$ and $\mathrm{pH} 6$ for $\mathrm{MO}$, the removal percentage was found to be constant. The optimum $\mathrm{pH}$ values for the removal of $\mathrm{MO}$ and $\mathrm{MB}$ were found to be 6 and 8 , respectively. In alkaline condition, the adsorption of MO onto the GCM was lower and was possibly due to the existence of $\mathrm{OH}^{-}$ions on the adsorbent surface, which competes with the anionic dye. ${ }^{25}$ However, the best results were obtained at neutral $\mathrm{pH}$ for both dyes.

\section{3. Equilibrium Adsorption Isotherm}

The Langmuir isotherm as shown in Eq. 4 is widely used in the scientific assessment of the adsorption process. This model assumes that the adsorbent surface can only occur at the surface monolayer and adsorption follows homogeneously. ${ }^{12}$

$$
\mathrm{C}_{\mathrm{e}} / \mathrm{q}_{\mathrm{e}}=\left(1 / \mathrm{Q}_{0} \mathrm{~b}\right)+\left(1 / \mathrm{Q}_{0}\right) \mathrm{Ce}
$$

In equation (4), $\mathrm{C}_{\mathrm{e}}$ is the equilibrium concentration of $\mathrm{MB}$ or MO in solution $(\mathrm{mg} / \mathrm{L}), \mathrm{q}_{\mathrm{e}}$ is the amount of $\mathrm{MB}$ $(\mathrm{mg} / \mathrm{g})$ or $\mathrm{MO}(\mathrm{mg} / \mathrm{g})$ adsorbed on GCM at equilibrium, $\mathrm{Q}_{\mathrm{o}}$ is the maximum adsorption capacity $(\mathrm{mg} / \mathrm{g})$, and $\mathrm{b}$ is the Langmuir constant. The slope $1 / \mathrm{Q}_{\mathrm{o}}$ and intercept (1/ $\mathrm{bQ}_{\mathrm{o}}$ ) can be calculated by straight line equation obtained through a plot of $\mathrm{C}_{\mathrm{e}} / \mathrm{q}_{\mathrm{e}}$ and $\mathrm{C}_{\mathrm{e}}$ (Figs. 5a and $5 \mathrm{~b}$ ). The linear correlation coefficients $\mathrm{R}^{2}$ are 0.990 for $\mathrm{MB}$ and 0.976 for $\mathrm{MO}$, indicating that the adsorption of $\mathrm{MB}$ followed the Langmuir adsorption model. The calculated values of $\mathrm{Q}_{0}$ are 38.75 and $43.48 \mathrm{mg} / \mathrm{g}$ for $\mathrm{MB}$ and $\mathrm{MO}$, respectively, at $25^{\circ} \mathrm{C}$. The Langmuir parameters for both the $\mathrm{MB}$ and $\mathrm{MO}$ dyes are presented in Table 1.

Table 1. Isotherm parameters of $\mathrm{MB}$ and $\mathrm{MO}$ onto $\mathrm{GCM}$ at $25^{\circ} \mathrm{C}$ $(n=3$, the reported values are mean of three measurements).

\begin{tabular}{lccccccc}
\hline Dyes & \multicolumn{3}{c}{ Langmuir } & \multicolumn{3}{c}{ Freundlich } \\
& $\boldsymbol{Q}_{\boldsymbol{0}}(\mathbf{m g} / \mathbf{g})$ & $\boldsymbol{b}(\boldsymbol{L} \mathbf{. ~ m} / \mathbf{g})$ & $\boldsymbol{R}^{\mathbf{2}}$ & $\boldsymbol{K}_{\boldsymbol{F}}(\mathbf{m g} / \mathbf{g})$ & $\boldsymbol{n}$ & $\boldsymbol{R}^{\mathbf{2}}$ \\
\hline $\mathrm{MB}$ & 38.75 & 0.54 & 0.990 & 12.07 & 1.30 & 0.986 \\
$\mathrm{MO}$ & 43.48 & 0.52 & 0.976 & 13.87 & 1.27 & 0.995 \\
\hline
\end{tabular}

The linear form of the Freundlich isotherm is given in Figure $5 \mathrm{c}$ and $\mathrm{d}$ for $\mathrm{MB}$ and $\mathrm{MO}$ respectively, and its linear equation is shown here. ${ }^{26}$

$$
\log \mathrm{q}_{\mathrm{e}}=\ln \mathrm{K}_{\mathrm{F}}+(1 / \mathrm{n}) \ln \mathrm{C}_{\mathrm{e}}
$$

In equation (5), $\mathrm{q}_{\mathrm{e}}$ is the amount of $\mathrm{MB}$ or $\mathrm{MO}$ adsorbed at equilibrium $(\mathrm{mg} / \mathrm{g})$ and $\mathrm{C}_{\mathrm{e}}$ is the equilibrium concentration $\left(\mathrm{mg} / \mathrm{L}\right.$ ) of the $\mathrm{MB}$ or MO. $\mathrm{K}_{\mathrm{F}}$ and $1 / \mathrm{n}$ are the Freundlich binding constant and constant related to the surface heterogeneity, respectively. A straight line was obtained when plotted $\ln \mathrm{q}_{\mathrm{e}}$ against $\ln \mathrm{C}_{\mathrm{e}}$ (Fig. $5 \mathrm{c}$ and $\mathrm{d}$ ) and $\mathrm{n}$ and $\mathrm{K}_{\mathrm{F}}$ were obtained from the slopes and intercepts, respectively. The Freundlich constant $n$ was found to be 1.30 and 1.27 for $\mathrm{MB}$ and MO, respectively, when the value of $n$ is greater than 1 . This result demonstrates that the materials are heterogeneous in nature and could thus adsorb MB or MO successfully. The adsorption data of MB was better fitted by the 
a)

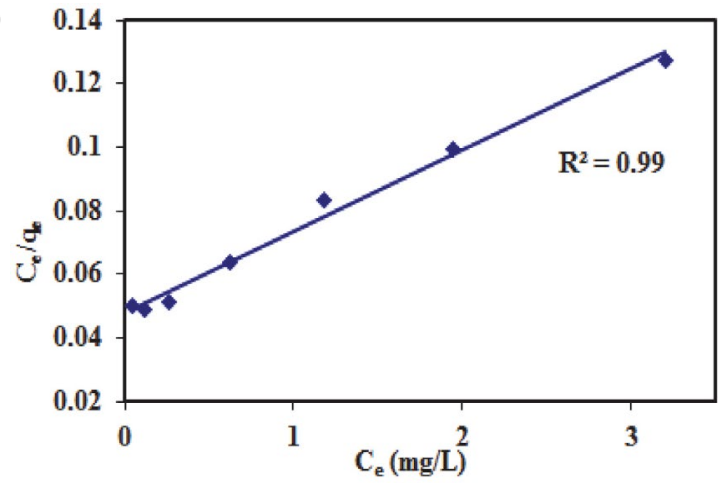

c)

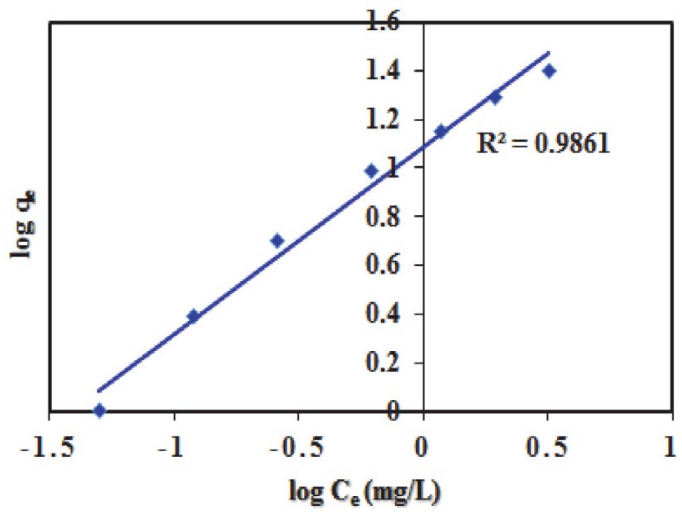

b)

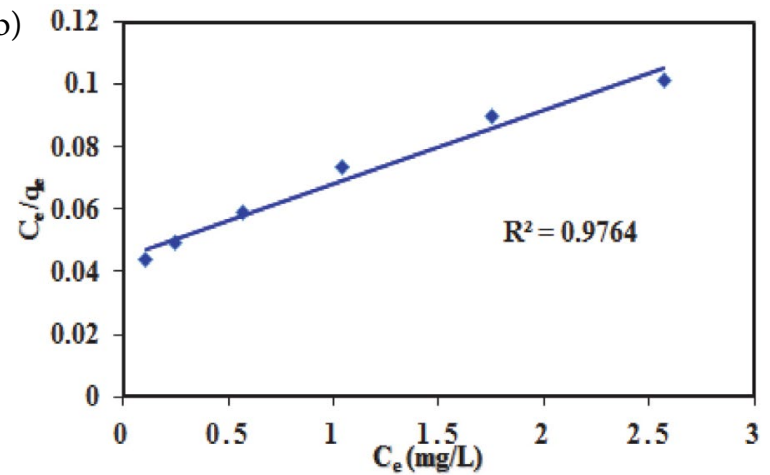

d)

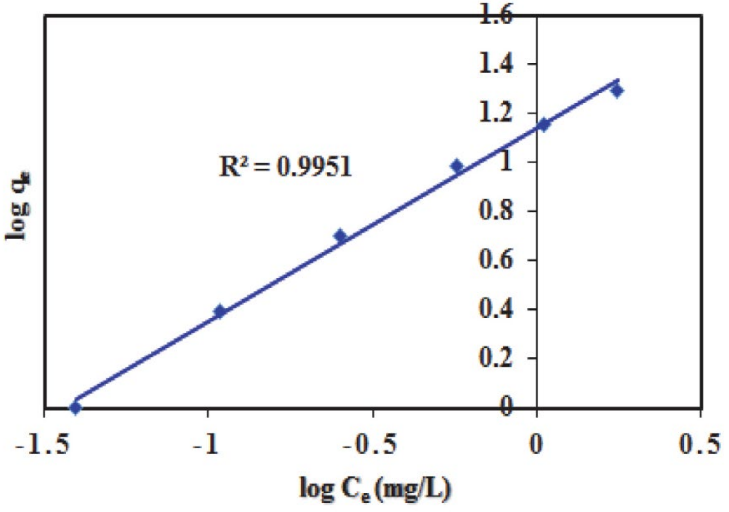

Figure 5. Langmuir adsorption isotherm of $\mathrm{MB}(\mathrm{a})$ and $\mathrm{MO}(\mathrm{b})$ and Freundlich isotherms of $\mathrm{MB}$ (c) and $\mathrm{MO}$ (d) (experimental condition: $\mathrm{MB} / \mathrm{MO}$ concentrations $=5,10,20,30,40$, and $50 \mathrm{mg} / \mathrm{L}$, adsorbent dose $=2 \mathrm{~g} / \mathrm{L}, \mathrm{pH}=8$ for $\mathrm{MB}$ and $\mathrm{pH} 6$ for $\mathrm{MO}$, temperature $=25^{\circ} \mathrm{C}$ ).

Langmuir isotherm $\left(\mathrm{R}^{2}=0.99\right)$ compared to the Freundlich isotherm; however, adsorption data of MO fitted well with the Freundlich isotherm $\left(\mathrm{R}^{2}=0.995\right)$ in comparison to the Langmuir isotherm (Table 1). Hence, the overall isotherm results demonstrated that the adsorption process of $\mathrm{MB}$ and MO onto GCM is complexed. The obtained adsorption capacity of GCM for MB and MO was comparable or near with the reported the similar type of materials such as activated carbons and graphene or its composites (Table 2) indicates that the GCM was potentially applicable for adsorption removal of dyes as it is reported methods.

\section{4. Kinetic Study of Removal of MB or MO}

A kinetics study for the adsorption of $\mathrm{MB}$ or $\mathrm{MO}$ onto the GCM was carried out under the following experimental condition: $\mathrm{pH} 8$ for $\mathrm{MB}, \mathrm{pH} 6$ for $\mathrm{MO}$, a dose of $4.0 \mathrm{~g} / \mathrm{L}$, and temperature of $25^{\circ} \mathrm{C}$. A kinetic study was conducted with six different initial concentrations $(5,10,20,30,40$, and 50 $\mathrm{mg} / \mathrm{L}$ ) to recognize the adsorption kinetics (Fig. 6). It was observed that the kinetic equilibrium for adsorption of the $\mathrm{MB}$ and MO on the GCM was reached at $180 \mathrm{~min}$, and the adsorption capacity of these dyes onto GCM increases with increasing initial concentration. The adsorption of the dyes ( $\mathrm{MB}$ and $\mathrm{MO}$ ) molecule increases with the increasing initial concentration, which might be due to the initial concentrations of dye, offering a driving force to restrain the mass transfer conflict of the dye molecules between the liquid phases and the solid phases. ${ }^{27}$ The kinetic parameters of the adsorption of the $\mathrm{MB}$ and $\mathrm{MO}$ on GCM-water interface was studied by applying the pseudo-first-order and pseudo-second-order kinetic models for the data, with initial dye con-

Table 2. Comparison of GCM adsorption capacity with previous reported activated carbons and graphene materials.

\begin{tabular}{|c|c|c|c|}
\hline \multirow[t]{2}{*}{ Adsorbents } & \multicolumn{2}{|c|}{ Adsorption capacity (mg/g) } & \multirow[t]{2}{*}{ References } \\
\hline & MB & MO & \\
\hline GCM & 38.75 & 43.48 & (This work) \\
\hline Charcoal & 62.70 & - & (Rafatullah et al., 2010) $)^{5}$ \\
\hline Activated carbon & 9.81 & - & (Rafatullah et al., 2010) ${ }^{5}$ \\
\hline Zeolite-rGO & 53.30 & - & $(\text { Zhu et al., 2014) })^{13}$ \\
\hline Ferric oxide-biochar $\left(\mathrm{Fe}_{2} \mathrm{O}_{3}-\mathrm{BC}\right)$ & - & 20.53 & (Chaukura et al., 2017) ${ }^{16}$ \\
\hline Multiwalled carbon nanotubes (MWCNT) & - & 50.25 & $(\text { Yao et al., 2011) })^{17}$ \\
\hline
\end{tabular}


centrations of $5,10,20,30,40$, and $50 \mathrm{mg} / \mathrm{L}$. In this study, the Lagergren's pseudo-first-order kinetic mode ${ }^{28}$ was applied to assess the adsorption rate, as expressed in Eq. 6.

$$
\log \left(\mathrm{q}_{\mathrm{e}}-\mathrm{q}_{\mathrm{t}}\right)=\log \mathrm{q}_{\mathrm{e}}-\left(\mathrm{k}_{\mathrm{l}} / 2.303\right) \mathrm{t}
$$

where $\mathrm{k}_{1}$ is the rate constant of the pseudo-first-order kinetic equation, and $\mathrm{q}_{\mathrm{t}}$ and qe are the adsorption masses of $\mathrm{MB}$ or MO onto GCM at time $t$ and at equilibrium, respectively. The $\mathrm{q}_{\mathrm{e}}$ values were calculated from Figure $6 \mathrm{a}$ and $6 \mathrm{~b}$ and the results reported in Table 3 . The $\mathrm{R}^{2}$ value of the plot was found to be in the range from 0.694 to 0.882 for MB; however, the $\mathrm{R}^{2}$ value for MO was found to be in the range of from 0.533 to 0.996 . The calculated value of $\mathrm{q}_{\mathrm{e}}(15.6 \mathrm{mg} / \mathrm{g})$ for MB was observed to be lower than that of the theoretical values $(23.96 \mathrm{mg} / \mathrm{g})$ for the highest initial concentration $(50$ $\mathrm{mg} / \mathrm{L})$. The calculated value of $\mathrm{q}_{\mathrm{e}}$ for $\mathrm{MO}(2.1 \mathrm{mg} / \mathrm{g})$ was found to be lower than that of the theoretical values (34.5 $\mathrm{mg} / \mathrm{g}$ ) for the highest initial concentration $(50 \mathrm{mg} / \mathrm{L})$.

The linear form of pseudo-second-order kinetics is indicated by Eq. $7^{29}$ as

$$
\mathrm{t} / \mathrm{q}_{\mathrm{t}}=1 /\left(\mathrm{k}_{2} \mathrm{qe}^{2}\right)+\left(1 / \mathrm{q}_{\mathrm{e}}\right) \mathrm{t}
$$

where $\mathrm{k}_{2}$ is the pseudo-second-order adsorption rate constant. The values of $\mathrm{k}_{2}$ and $\mathrm{q}_{\mathrm{e}}$ for $\mathrm{MB}$ and $\mathrm{MO}$ were calcu- lated from the slope and intercept of plots of $t / q_{t}$ versus $t$ as presented in Figure $6 \mathrm{c}$ and $6 \mathrm{~d}$. The $\mathrm{R}^{2}$ values for both dyes were found to be greater than 0.99 , representing the better fit of the pseudo-second-order model than the pseudo-first-order kinetic model (Table 3).

The empirical model described by Weber and Morris (1963) was applied for the evaluation of the intra-particle diffusion mechanism. This process is generally the rate-controlling phase in most of the adsorption processes. In this process, the adsorbate is possibly transferred from the bulk phase of the solution to the solid phase. ${ }^{30}$

The intra-particle diffusion model can be represented as follows (Eq. 8):

$$
\mathrm{q}_{\mathrm{t}}=\mathrm{k}_{\mathrm{i}} \mathrm{t}^{1 / 2}+\mathrm{C} \text {, }
$$

where $k_{\mathrm{i}}$ is the intraparticle diffusion rate constant and $\mathrm{C}$ is represented as a constant.

The $\mathrm{k}_{\mathrm{i}}$ values can be calculated from the linear plots of the adsorbate uptake $\left(\mathrm{q}_{\mathrm{t}}\right)$ versus the square root of time $\left(t^{1 / 2}\right)$ (Fig. 7). In the present study, the linear plots are not passed through the origin, it confirms that the intra-particle diffusion was not the only rate-controlling step occurring in the adsorption process. However, the intra-particle diffusion curves do not fully concur with the linear fitting. This suggests that intra-particle diffusion along with out-
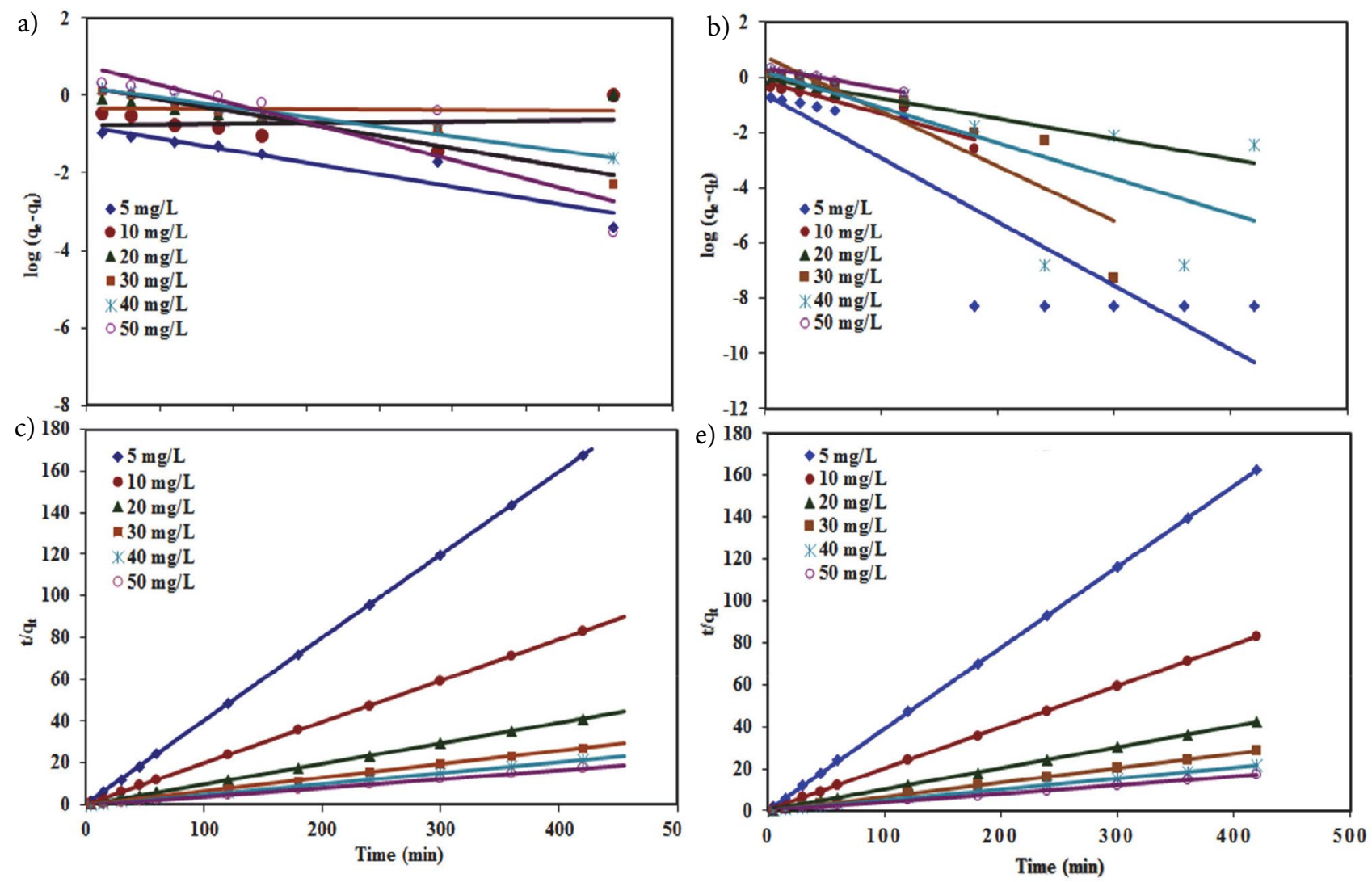

Figure 6. Pseudo-first-order kinetic model for MB (a) and MO (b), and pseudo-second-order kinetics model for MB (c) and MO (d) (experimental conditions: $\mathrm{MB} / \mathrm{MO}$ concentrations $=5,10,20,30,40$, and $50 \mathrm{mg} / \mathrm{L}$, adsorbent dose $=2 \mathrm{~g} / \mathrm{L}, \mathrm{pH} 8$ for $\mathrm{MB}$ and $\mathrm{pH} 6$ for $\mathrm{MO}$, temperature $=25^{\circ} \mathrm{C}$ ). 

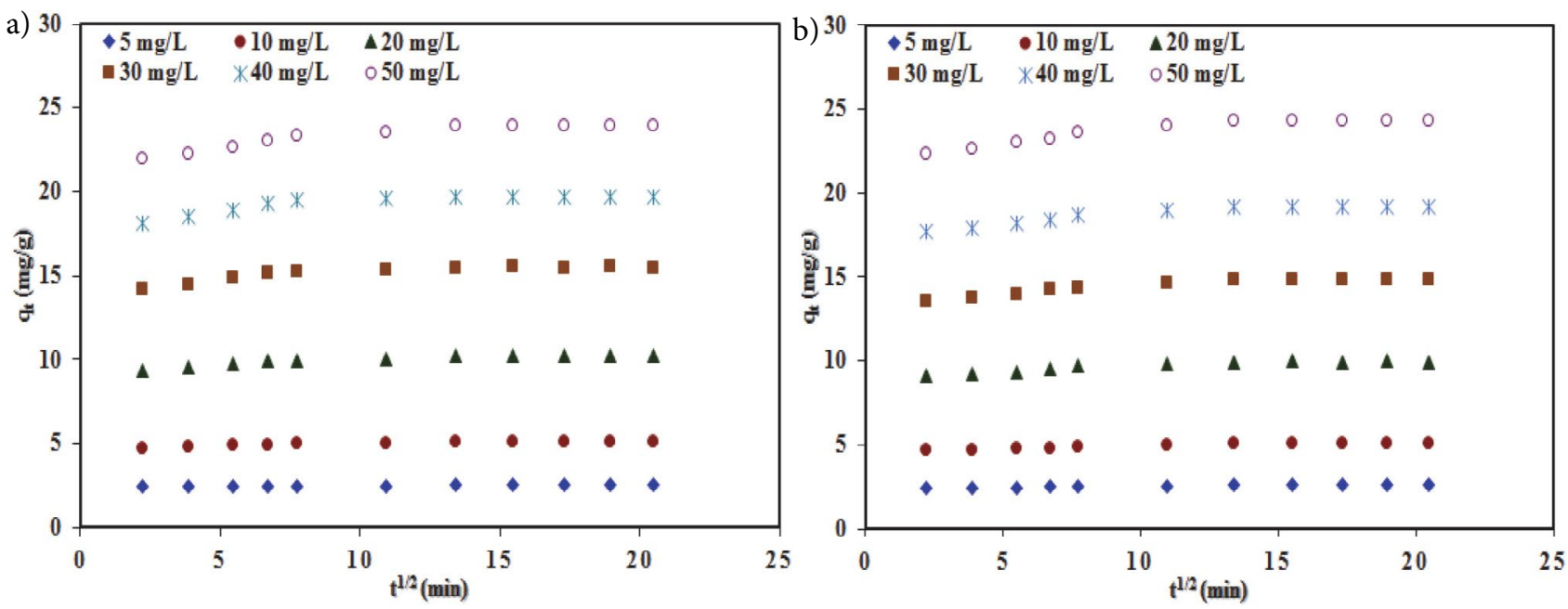

Figure 7. Intra-particle diffusion plots for the removal of MB (a) and MO (b) by GCM (MB/MO concentration $=5,10,20$, 30, 40, and $50 \mathrm{mg} / \mathrm{L}$, adsorbent dose $=2 \mathrm{~g} / \mathrm{L}, \mathrm{pH} 8$ for $\mathrm{MB}$ and $\mathrm{pH} 6$ for $\mathrm{MO}$ for, temperature $=25^{\circ} \mathrm{C}$ ).

Table 3. Kinetic parameters of MB and MO sorption onto GCM at $25^{\circ} \mathrm{C}(\mathrm{n}=3$, the reported values are mean of three measurements).

\begin{tabular}{|c|c|c|c|c|c|c|c|c|c|c|c|}
\hline \multirow[t]{2}{*}{ Dyes } & \multirow{2}{*}{$\begin{array}{l}\text { The initial } \\
\text { concentration } \\
\text { of dyes }(\mathrm{mg} / \mathrm{L})\end{array}$} & \multirow{2}{*}{$\begin{array}{l}q_{e}, T h \\
\quad(\mathrm{mg} / \mathrm{g})\end{array}$} & \multicolumn{3}{|c|}{ Pseudo-First-Order } & \multicolumn{3}{|c|}{ Pseudo-second-order } & \multicolumn{3}{|c|}{ Weber and Morris } \\
\hline & & & $\begin{array}{c}q_{e, C a l} \\
(\mathbf{m g} / \mathbf{g})\end{array}$ & $\mathrm{K}_{1}$ & $\mathbf{R}^{2}$ & $\begin{array}{c}q_{e, C a l} \\
(\mathbf{m g} / \mathrm{g})\end{array}$ & $\mathbf{K}_{2}$ & $\mathbf{R}^{2}$ & $\mathbf{K}_{\mathbf{i}}$ & $\mathrm{C}$ & $\mathbf{R}^{2}$ \\
\hline \multirow[t]{6}{*}{$\mathrm{MB}$} & 5 & 2.50 & 1.97 & 0.065 & 0.882 & 2.51 & 0.580 & 1 & 0.006 & 2.413 & 0.837 \\
\hline & 10 & 5.06 & 1.87 & 0.004 & 0.782 & 5.07 & 0.980 & 1 & 0.018 & 4.764 & 0.796 \\
\hline & 20 & 10.22 & 4.62 & 0.009 & 0.801 & 10.27 & 0.070 & 0.999 & 0.043 & 9.499 & 0.826 \\
\hline & 30 & 15.51 & 9.34 & 0.014 & 0.697 & 15.56 & 0.061 & 0.999 & 0.063 & 14.456 & 0.738 \\
\hline & 40 & 19.74 & 13.8 & 0.017 & 0.700 & 19.76 & 0.056 & 1 & 0.0731 & 18.509 & 0.728 \\
\hline & 50 & 23.96 & 15.6 & 0.044 & 0.797 & 24.06 & 0.027 & 1 & 0.109 & 22.114 & 0.853 \\
\hline \multirow[t]{6}{*}{$\mathrm{MO}$} & 5 & 4.71 & 0.23 & 0.053 & 0.813 & 2.59 & 0.312 & 1 & 0.01 & 2.417 & 0.855 \\
\hline & 10 & 8.90 & 0.69 & 0.027 & 0.898 & 5.09 & 0.122 & 0.999 & 0.024 & 4.665 & 0.878 \\
\hline & 20 & 16.77 & 0.89 & 0.017 & 0.971 & 10.0 & 0.066 & 0.998 & 0.047 & 9.166 & 0.850 \\
\hline & 30 & 23.69 & 5.62 & 0.046 & 0.796 & 14.90 & 0.044 & 1 & 0.069 & 13.658 & 0.854 \\
\hline & 40 & 28.36 & 1.56 & 0.030 & 0.533 & 19.31 & 0.036 & 0.999 & 0.085 & 17.776 & 0.853 \\
\hline & 50 & 34.50 & 2.10 & 0.017 & 0.996 & 24.39 & 0.029 & 1 & 0.108 & 22.482 & 0.858 \\
\hline
\end{tabular}

er-sphere diffusion was involved in the rate-controlling step for the adsorption process.

\section{5. Thermodynamic Studies}

The thermodynamic parameter such as Gibbs free energy change $\left(\Delta \mathrm{G}^{0}\right)$, the enthalpy change $\left(\Delta \mathrm{H}^{0}\right)$ and the entropy change $\left(\Delta S^{0}\right)$ of the present system are illustrated from Figure 8 and reported in Table 4, which can provide an important information regarding adsorption process. The thermodynamic parameters can be illustrating from the following Van't Hoff equation:

$$
-R T \log K_{c}=\Delta H^{0}-T \Delta S^{0}
$$

As we know, $\Delta \mathrm{G}^{0}=$, where $\mathrm{R}(0.008314 \mathrm{~kJ} / \mathrm{mol}$. $\mathrm{K})$ is universal gas constant, $\mathrm{T}(\mathrm{K})$ is the temperature and $\mathrm{Kc}=\mathrm{q}_{\mathrm{e}} /$ $\mathrm{C}_{\mathrm{e}}$ at equilibrium. From the Table 4, it was clearly observed that the resultant $\Delta \mathrm{G}^{0}$, is negatively increased with initial concentration with positive $\Delta \mathrm{H}^{0}$ and $\Delta \mathrm{S}^{0}$. The resultant thermodynamic parameters revealed the favor of adsorption process, was the spontaneous endothermic process. However, Table 4 reveals, the increased $K_{c}$ with increasing temperature, which indicate chemical interactions between the adsorbate and adsorbent. ${ }^{31,32}$ In addition, the resultant $\Delta \mathrm{H}^{0}$ and $\Delta \mathrm{S}^{0}$ values are supports the present system percentage of adsorption data, where a higher rate of adsorption is found for low initial dye concentration with high $\Delta \mathrm{H}^{0}$ and $\Delta \mathrm{S}^{0}$, and a low rate of adsorption is observed for a high initial concentration with low $\Delta \mathrm{H}^{0}$ and $\Delta \mathrm{S}^{0}$.

\section{6. Possible Adsorption Mechanism of MB and MO onto GCM}

From FT-IR and XPS studies (Fig. 3) of dyes loaded GCM, it was concluded that the adsorption process of MB 
a)

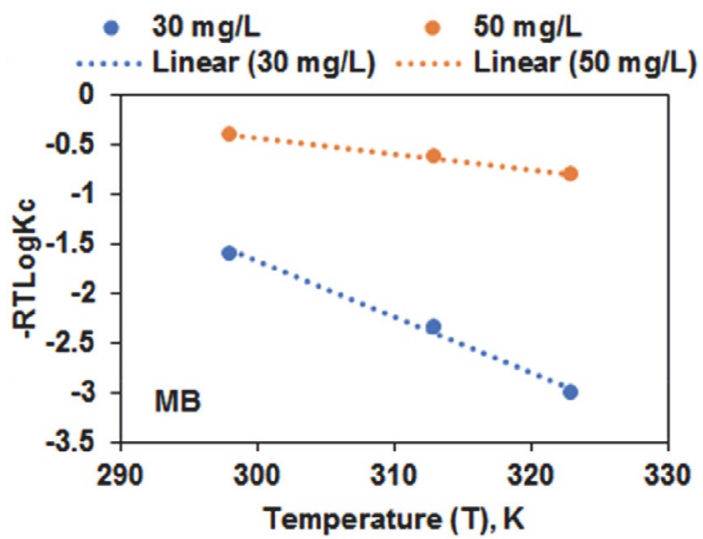

b)

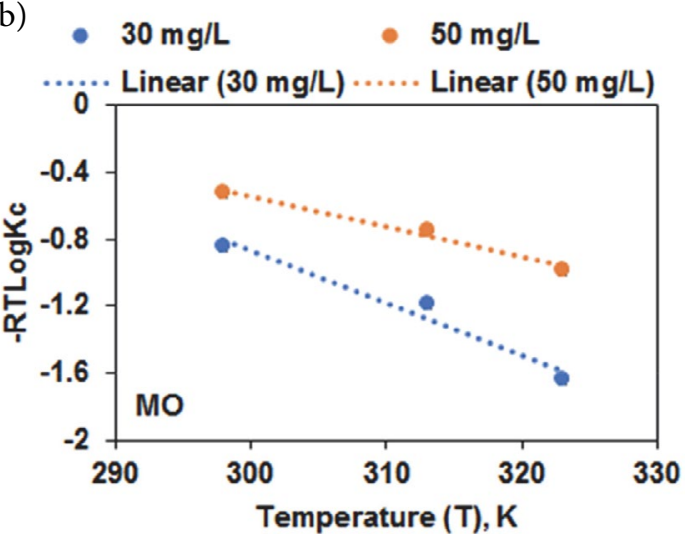

Figure 8. Thermodynamic illustrations $\left(\Delta \mathbf{G}^{0}=-\mathrm{RT} \log K c\right.$ vs. T) of MB and MO adsorption onto GCM at $\mathrm{pH} 8.0$ for $\mathrm{MB}$ and $\mathrm{pH} 6.0$ for MO with $2.0 \mathrm{~g} / \mathrm{L}$ adsorbent dosage for $180 \mathrm{~min}$ equilibrium for calculating to thermodynamic parameters $\Delta \mathbf{H}^{0}$ and $\Delta \mathbf{S}^{0}$.

and MO onto GCM can be caused by the interaction of dyes with organic functions such as carbonyl, epoxy or carboxylic groups on the surface of as prepared GCM. From Figure 3 , it was clearly observed that the organic functional groups at GCM altering their positions by adsorption of $\mathrm{MB}$ and MO dyes. It may be the chemical interaction between dyes $(\mathrm{MB} / \mathrm{MO})$ and surface functional groups of GCM. Further, it was proved from thermodynamic, kinetic isotherms and $\mathrm{pH}$ studies, the adsorption of $\mathrm{MB}$ or $\mathrm{MO}$ was endothermic chemical interaction through diffusion.

\section{Conclusions}

A graphitic carbon-like material (GCM) was prepared from edible sugar used as an absorbent, which was highly effective for the removal of methylene blue (MB) and methyl orange (MO) from its aqueous solution. In this study, it was confirmed that the adsorption was affected by $\mathrm{pH}$, dosage amount, and the initial concentration of both dyes. The removal efficiencies of $\mathrm{MB}$ and $\mathrm{MO}$ onto the GCM increased with an increase in the dosages of adsorbent up to a certain limit and then became constant. The initial solutions of $\mathrm{pH} 6$ and $\mathrm{pH} 8$ were found to be optimum for the removal of MO and MB, respectively. However, the removal efficiency decreased for both dyes when the initial concentrations were increased from 5 to $50 \mathrm{mg} / \mathrm{L}$.
While the equilibrium data were well fitted to the Langmuir isotherm model for MB, for MO, they were well fitted to the Freundlich model. The experimental data of both dyes fitted better with the pseudo-second-order model than compared with the pseudo-first-order model. The resultant thermodynamic parameters concluded that the adsorption process was endothermic with spontaneous at interfaces of equilibrium. From thermodynamic, kinetic and $\mathrm{pH}$ studies, it was also concluded that the adsorption process was through the chemical interaction between adsorbent and adsorbate. In this study, the GCM synthesized from the edible sugar can be used as a potential adsorbent in the treatment of wastewater containing dye for effective removal performance and thereby significantly reducing human health and environmental risks. Moreover, the obtained adsorption capacity of GCM for MB and MO was comparable or near with the reported similar type of materials such as activated carbons and graphene or its composites. Hence, as prepared GCM has potential adsorption capacity for the removal organic dye pollutants and thereby significantly reducing human health and environmental risks.

\section{Acknowledgments}

This research was supported by Startup Research Program through the National Research Foundation of

Table 4. Thermodynamic parameters of $\mathrm{MB}$ and $\mathrm{MO}$ onto GCM at $\mathrm{pH} 8.0$ for $\mathrm{MB}$ and $\mathrm{pH} 6.0$ for $\mathrm{MO}, 2.0 \mathrm{~g} / \mathrm{L}$ dosage and180 min equilibrium time in the range of temperature, $298-323 \pm 0.5 \mathrm{~K}(\mathrm{n}=3$, the reported values are mean of three measurements).

\begin{tabular}{|c|c|c|c|c|c|c|c|c|c|c|}
\hline \multirow{2}{*}{$\begin{array}{l}\text { Name } \\
\text { of dye }\end{array}$} & \multirow{2}{*}{$\begin{array}{l}\text { Dye initial concen- } \\
\text { tration, } \mathrm{mg} / \mathrm{L}\end{array}$} & \multicolumn{3}{|c|}{$K_{c}=q_{e} / C_{e}, \mathrm{~L} / \mathrm{g}$} & \multicolumn{3}{|c|}{$\Delta \mathrm{G}^{0}=-\mathrm{RT} \log K c \mathrm{~kJ} / \mathrm{mol}$} & \multirow{2}{*}{$\begin{array}{c}\Delta \mathrm{H}^{0}, \\
\mathrm{~kJ} / \mathrm{mol}\end{array}$} & \multirow{2}{*}{$\begin{array}{c}\Delta \mathrm{S}^{0}, \\
\mathrm{~kJ} / \mathrm{mol} \mathrm{K}\end{array}$} & \multirow[t]{2}{*}{$\mathbf{R}^{2}$} \\
\hline & & $298 \mathrm{~K}$ & $313 \mathrm{~K}$ & $323 \mathrm{~K}$ & $298 K$ & $313 \mathrm{~K}$ & $323 \mathrm{~K}$ & & & \\
\hline \multirow[t]{2}{*}{$\mathrm{MB}$} & 30.00 & 4.40 & 7.92 & 13.09 & -1.59 & -2.34 & -2.99 & 15.02 & 0.056 & 0.994 \\
\hline & 50.00 & 1.44 & 1.74 & 1.99 & -0.39 & -0.63 & -0.80 & 4.45 & 0.016 & 0.999 \\
\hline \multirow[t]{2}{*}{$\mathrm{MO}$} & 30.00 & 2.19 & 2.84 & 4.07 & -0.84 & -1.18 & -1.64 & 8.43 & 0.310 & 0.959 \\
\hline & 50.00 & 1.63 & 1.94 & 2.32 & -0.52 & -0.75 & -0.98 & 4.90 & 0.018 & 0.985 \\
\hline
\end{tabular}


Korea (NRF) funded by Ministry of Science, ICT \& Future Planning (MSIP) (2017R1C1B5016656) and partially supported by Kwangwoon University Research Grant-2018.

\section{Author Disclosure Statement}

No competing financial interests exist.

\section{References}

1. X. Rong, F. Qiu, C. Zhang, L. Fu, Y. Wang and D. Yang, J. Powder Technol. 2015, 275, 322-328.

DOI:10.1016/j.powtec.2015.01.079

2. T. Madrakian, A. Afkhami, M. Ahmadi and H. Bagheri, J. Hazard. Mater. 2011, 196, 109-114.

DOI:10.1016/j.jhazmat.2011.08.078

3. M. S. Sajab, C. H. Chia, S. Zakaria and P. S. Khiew, Bioresource Technol. 2013, 128, 571-577.

DOI:10.1016/j.biortech.2012.11.010

4. P. Sivakumar and P. Palanisamy, Int. J. Chem.Tech. Res. 2009, 1, 502-510.

5. M. Rafatullah, O. Sulaiman, R. Hashim and A. Ahmad, J. Hazard. Mater. 2010, 177, 70-80.

DOI:10.1016/j.jhazmat.2009.12.047

6. A. Mittal, A. Malviya, D. Kaur, J. Mittal and L. Kurup, J. Hazard. Mater. 2007, 148, 229-240.

DOI:10.1016/j.jhazmat.2007.02.028

7. E. Haque, J. W. Jun and S. H. Jhung, J. Hazard. Mater. 2011, 185, 507-511. DOI:10.1016/j.jhazmat.2010.09.035

8. D. Eom, D. Prezzi, K. T. Rim, H. Zhou, M. Lefenfeld, S. Xiao, C. Nuckolls, M. S. Hybertsen, T. F. Heinz and G. W. Flynn, Nano Lett. 2009, 9, 2844-2848. DOI: 10.1021/nl900927f

9. A. A. Balandin, S. Ghosh, W. Bao, I. Calizo, D. Teweldebrhan, F. Miao and C. N. Lau, Nano Lett. 2008, 8, 902-907. DOI: $10.1021 / \mathrm{nl} 0731872$

10. S. Latil and L. Henrard, Phys. Rev. Lett. 2006, 97, 036803. DOI: 10.1103/PhysRevLett.97.036803

11. R. Li, C. Chang, J. Zhou, L. Zhang, W. Gu, C. Li, S. Liu and S. Kuga, Ind. Eng. Chem. Res. 2010, 49, 11380-11384. DOI: $10.1021 /$ ie $101144 \mathrm{~h}$

12. H. Shi, W. Li, L. Zhong and C. Xu, Ind. Eng. Chem. Res. 2014, 53, 1108-1118. DOI: $10.1021 /$ ie4027154

13. J. Zhu, Y. Wang, J. Liu and Y. Zhang, Ind. Eng. Chem. Res. 2014, 53, 13711-13717. DOI: 10.1021/ie502030w
14. J. S. Cha, S. H. Park, S.-C. Jung, C. Ryu, J.-K. Jeon, M.-C. Shin and Y.-K. Park, J. Ind. Eng. Chem. 2016, 40, 1-15.

DOI: $10.1016 /$ j.jiec.2016.06.002

15. S. S. Gupta, T. S. Sreeprasad, S. M. Maliyekkal, S. K. Das and T. Pradeep, ACS Appl. Mater. Interf. 2012, 4, 4156-4163. DOI: $10.1021 / \mathrm{am} 300889 \mathrm{u}$

16. N. Chaukura, E. C. Murimba and W. Gwenzi, Appl. Water Sci. 2017, 7, 2175-2186. DOI: 10.1007/s13201-016-0392-5

17. Y. Yao, H. Bing, X. Feifei and C. Xiaofeng, Chem. Eng. J. 2011, 170, 82-89. DOI: 10.1016/j.cej.2011.03.031

18. X.-L. Wu, Y. Shi, S. Zhong, H. Lin and J.-R. Chen, Appl. Surf. Sci. 2016, 378, 80-86. DOI: 10.1016/j.apsusc.2016.03.226

19. Y. Gokce and Z. Aktas, Appl. Surf. Sci. 2014, 313, 352-359. DOI: $10.1016 /$ j.apsusc.2014.05.214

20. J. Singh, K. J. Reddy, Y.-Y. Chang, S.-H. Kang and J.-K. Yang, Proc. Saf. Environ. Prot. 2016, 99, 88-97.

DOI:10.1016/j.psep.2015.10.011

21. L. P. Lingamdinne, H. Roh, Y.-L. Choi, J. R. Koduru, J.-K. Yang and Y.-Y. Chang, J. Ind. Eng. Chem. 2015, 32, 178-186. DOI:10.1016/j.jiec.2015.08.012

22. R. Gong, Y. Ding, M. Li, C. Yang, H. Liu and Y. Sun, Dyes and Pigments 2005, 64, 187-192.

DOI:10.1016/j.dyepig.2004.05.005

23. J. Fu, Z. Chen, M. Wang, S. Liu, J. Zhang, J. Zhang, R. Han and Q. Xu, Chem. Eng. J. 2015, 259, 53-61.

DOI:10.1016/j.cej.2014.07.101

24. L. Borah, M. Goswami and P. Phukan, J. Environ. Chem. Eng. 2015, 3, 1018-1028. DOI:10.1016/j.jece.2015.02.013

25. E. N. El Qada, S. J. Allen and G. M. Walker, Chem. Eng. J. 2008, 135, 174-184. DOI:10.1016/j.cej.2007.02.023

26. B. Hameed and A. Ahmad, J.Hazard. Mater. 2009, 164, 870875. DOI:10.1016/j.jhazmat.2008.08.084

27. P. Sharma, H. Kaur, M. Sharma and V. Sahore, Environ. Monit. Assess. 2011, 183, 151-195. DOI:10.1007/s10661-011-1914-0

28. K. Periasamy and C. Namasivayam, Ind. Eng. Chem. Res. 1994, 33, 317-320. DOI: 10.1021/ie00026a022

29. Y. Li, Q. Du, T. Liu, J. Sun, Y. Wang, S. Wu, Z. Wang, Y. Xia and L. Xia, Carbohyd. Polymers 2013, 95, 501-507.

DOI: $10.1016 /$ j.carbpol.2013.01.094

30. M. Doğan, H. Abak and M. Alkan, J. Hazard. Mater. 2009, 164, 172-181. DOI:10.1016/j.jhazmat.2008.07.155

31. L. P. Lingamdinne, Y.-Y. Chang, J.-K. Yang, J. Singh, E.-H. Choi, M. Shiratani, J. R. Koduru and P. Attri, Chem. Eng. J. 2017, 307, 74-84. DOI: 10.1016/j.cej.2016.08.067

32. C. N. R. Rao, A. K. Sood, K. S. Subrahmanyam and A. Govindaraj, Ange. Chem. Int. Ed. 2009, 48, 7752-7777.

DOI:10.1002/anie.200901678 


\section{Povzetek}

Grafitu podobni material (ang. graphitic carbon-like material-GCM), proizveden iz jedilnega sladkorja pod atmosfero dušika, smo uporabili kot adsorbent za odstranjevanje anionskih in kationskih barvil (metil oranžno-MO ter metilensko modro-MB) iz odpadnih vod. Za fizikalno-kemijsko karakterizacijo GCM smo uporabili vrstično elektronsko mikroskopijo (SEM), rentgensko difrakcijo (XDS), infrardečo spektroskopijo s Fourierjevo transformacijo (FTIR) in rentgensko fotoelektronsko spektroskopijo (XPS). Iz SEM-a je bila razvidna ploščičasta morfologija povprečne velikosti 50-100 nm. S pomočjo BET smo določili specifično površino $574 \mathrm{~m} 2 / \mathrm{g}$ in volumen por $0.248 \mathrm{~cm}^{3} / \mathrm{g}$ s povprečno velikostjo por $1.847(<2 \mathrm{~nm})$ kar uvršča GCM med mikroporozne materiale. Preučili smo vpliv količine, $\mathrm{pH}$ vrednosti, kontaktnega časa in koncentracije na adsorpcijo MB in MO. Eksperimentalno določene izoterme MB smo lahko opisali z Langmuirjevo izotermo $\left(R^{2}=0.990\right)$ medtem ko smo adsorpcijo MO bolje opisali s Freundlichovo izotermo $\left(R^{2}=0.995\right)$. Maksimalna adsorpcijska kapaciteta določena na osnovi opisa podatkov z Langmuirjevo izotermo je bila pri $25^{\circ} \mathrm{C}$ enaka $38.75 \mathrm{mg} / \mathrm{g}$ za MB in $43.48 \mathrm{mg} / \mathrm{g}$ za MO, kar dokazuje, da je GCM primeren za adsorpcijo tako anionskih kot kationskih barvil. Hitrost adsorpcije obeh barvil na GCM smo lahko opisali s kinetiko pseudo-drugega reda. Termodinamski parametri so pokazali, da je adsorpcija obeh barvil endotermna. Na osnovi dobljenih rezultatov lahko zaključimo, da je GCM potencialni adsorbent za odstranjevanje MB in MO iz vodnih raztopin. 